\title{
PEMBERDAYAAN RELAWAN BALARAJA MELALUI PELATIHAN MENULIS KARYA ILMIAH DAN MENULIS SASTRA
}

\author{
Ade Siti Haryanti, Astuti Samosir, Ila Nafilah \\ Universitas Indraprasta PGRI
}

\begin{abstract}
Abstrak
Pemilihan mitra dilakukan dengan sistem purposive sample (sampel bertujuan). Berdasarkan pengamatan dan wawancara informal terhadap para relawan di Balaraja maka dapat disimpulkan bahwa pelatihan menulis karya ilmiah dan sastra sangat diperlu untuk dilakukan. Metode atau teknik yang akan kami lakukan dalam pengabdian masyarakat ini adalah teknik active-learning, inkuiri, metode objek langsung, tanya jawab, deskriptif hingga pada praktek yang berkaitan dengan menulis karya ilmiah dan sastra. Peserta kegiatan ini adalah masyarakat Balaraja yang bergabung dalam Relawan "Pustaka Muda Mandiri", dan Relawan "Sekolah Anak Bahari" dan kelompok pemuda Balaraja. Mereka memiliki latar belakang yang beragam, ada yang berprofesi menjadi guru, karyawan serta mahasiswa dari berbagai jurusan dan universitas misalnya jurusan kedokteran, hubungan internasional, ekonomi, bimbingan konseling, sejarah, hukum dan sebagainya. Hasil dari penelitian sebagai berikut. Pertama, terjadi peningkatan dalam menulis karya ilmiah dan sastra. Kedua, melakukan publikasi. Ketiga, rancangan pelatihan selanjutnya.
\end{abstract}

Kata Kunci: Pemberdayaan Masyarakat, Menulis Karya Ilmiah, Menulis Sastra

\section{PENDAHULUAN}

\section{Hakikat Menulis Karya Ilmiah}

Karya ilmiah ditulis berdasarkan fakta dan dapat dibuktikan kebenarannya melalui penelitian yang dilakukan dan dapat dipertanggungjawabkan. Karakteristik keilmiahan sebuah karya terdapat pada isi, penyajian, dan bahasa yang digunakan. Sebuah tulisan dikategorikan sebagai karya ilmiah karena bersifat rasional, objektif, tidak memihak, dan berbicara apa adanya tanpa melakukan manipulasi data. Karya ilmiah sebagai suatu karya tulis nonfiksi karena berisi gagasan, pemecahan masalah, pemikiran konseptual, hasil pengamatan, dan hasil penelitian yang disusun secara sistematis dengan dukungan fakta/data, teori, dan buktibukti empiris yang menggunakan bahasa
Indonesia yang benar, lugas, efektif, dan dapat dipertanggungjawabkan kebenarannya secara objektif untuk kepentingan akademik. Banyak manfaat yang didapatkan jika seseorang mampu atau terampil dalam menulis karya ilmiah, karena dapat dimanfaatkan untuk keperluan kegiatan ilmiah, seperti seminar, lokakarya, diskusi, workshop, dan kegiatan ilmiah lainnya.

\section{Hakikat Menulis Sastra}

Menurut Abrams (dalam Wiyatmi, 2006: 18) mengemukakan bahwa "berdasarkan teori objektif sastra didefinisikan sebagai karya seni yang otonom, dapat berdiri sendiri, bebas dari pengarang, dan realitas dari pembaca". Berdasarkan teori ekspresif karya sastra dipandang sebagai ekspresi sastrawan sebagai curahan perasaan atau luapan perasaan dan pemikiran sastrawan, atau 
sebagai produk imajinasi sastrawan yang bekerja dengan persepsi-persepsi, pikiran-pikiran, atau perasaanperasaannya. Sastra merupakan kata serapan dari bahasa Sansekerta, yang mempunyai makna "teks yang mengandung instruksi" atau "pedoman", dari kata dasar sas- yang bermakna "instruksi" atau "ajaran". Dalam bahasa Indonesia kata ini biasanya digunakan untuk mengacu kepada kesusastraan atau sebuah tulisan yang mempunyai arti atau keindahan tertentu. Menurut Esten (2000: 7) mengatakan bahwa "secara etimologi menurut asal-usul kata kesusastraan berarti karangan yang indah". Jadi sastra adalah suatu tulisan atau karangan yang mengandung unsur keindahan dan biasanya mengandung pedoman.

Segmentasi sastra lebih mengacu sesuai defenisinya sebagai sekedar teks. "Sastra adalah dialektik pada berbagai tingkatnya antara dunia luar teks yaitu peristiwa dan dunia dalam teks yaitu makna. Intraksi teks dengan dunia luar teks menghasilkan makna referensial, sedangkan interaksi antara bagianbagian teks satu sama lain menghasilkan makna tekstual yang merupakan pencapaian spesifik dari kesusastraan" (Kleden, 2004: 8). Berdasarkan pengertian di atas dapat disimpulkan bahwa dalam teks karya sastra terjadi hubungan dua arah yaitu antara teks yang berhubungan dengan dunia luar dan teks dengan teks yang saling berhubungan.

Menurut Faruk (dalam Zulfahnur dkk. 2007: 2) mengemukakan bahwa "pengertian sastra mulanya amat luas, mencakup berbagai aktivitas dan hasil aktivitas bahasa tulis atau tulis-menulis". Seiring dengan meluasnya kebahasaan membaca ke berbagai cakupan. Pengertian tersebut menyempit dan mendefinisikan sastra sebagai aktivitas dan hasil aktivitas bahasa yang bersifat imajinatif, baik dalam hal kehidupan yang tergambar di dalamnya maupun dalam hal bahasa yang digunakan untuk menggambarkan kehidupan tersebut. Sastra menurut Ratna (2007: 458) menyatakan bahwa "sastra mula-mula berarti alat untuk mengajar, kemudian berarti kumpulan tulisan yang indah baik lisan maupun tulisan dengan hakikat kreativitas dan imajinatif'. Berdasarkan devinisi di atas, sastra merupakan media sarana baik secara lisan maupun tulisan untuk mengungkapkan hasil kreativitas dan imajinasi seseorang agar tersusun menjadi suatu karya yang indah agar dapat berguna sebagai alat untuk mengajar.

Berdasarkan teori-teori di atas sastra dapat disimpulkan sebagai suatu hasil karya manusia yang menggunakan bahasa sebagai medianya yang besifat imajinatif yang mengandung pemikiran dan ide seseorang berimajinasi baik secara objektif maupun subjektif yang mempunyai makna referensial maupun makna tekstual serta mengandung unsur keindahan.

\section{Jenis-jenis Karya Sastra}

1. Puisi

Menurut Situmorang (dalam Aswinarko dkk. 2013: 7) menyatakan bahwa "puisi berasal dari bahasa Yunani, yang juga dalam bahasa latin poietas (Latin Poeta). Mula-mula artinya pembangun, pembentuk, pembuat. Asal katanya poieo atau poio atau poeo yang artinya membangun, menyebabkan, menimbulkan menyair". Artinya yang mula-mula ini lama-kelamaan semakin di persempit ruang lingkupnya menjadi hasil seni sastra, yang katakatanya disusun menurut syarat-syarat tertentu dan menggunakan rama, dan kadangkadang kata kiasan.

Menurut Teeuw (dalam Pradopo, 2009: 3) menyatakan 
"hakikat puisi sebagai karya seni yang selalu terjadi ketegangan antara konvensi dan pembaharuan (inovasi)". Sepanjang zaman puisi seperti karya sastra yang lain selalu mengalami perubahan dan perkembangan. Berdasarkan teori tersebut hakikat puisi selalu berubah dan mengikuti perkembangan zaman. Pengertian yang diberikan seseorang biasanya berhubungan dengan struktur fisik dan struktur batin saja, namun ada juga yang memberikan batasan yang meliputi keduanya. Puisi adalah rangkaian kata yang sangat padu. Oleh karena itu, kejelasan sebuah puisi sangat bergantung pada ketepatan penggunaan kata serta kepaduan yang membentuknya.

\section{Novel}

"Istilah novel berasal dari bahasa Itali novella, yang mengandung makna harfiah sebuah barang baru yang kecil, yang kemudian diartikan sebagai cerita pendek dalam bentuk prosa" (Nurgiyantoro, 2009: 9). Lebih jauh, Nurgiyantoro (2009: 10) menambahkan bahwa "dewasa ini novel dideskripsikan sebuah karya prosa fiksi yang cukup panjang tidak terlalu panjang namun tidak terlalu pendek". Novel ialah suatu karangan prosa yang bersifat cerita, yang menceritakan suatu kejadian yang luar biasa dari kehidupan orangorang (tokoh cerita). Dikatakan kejadian yang luar biasa karena dari kejadian ini lahir suatu konflik, suatu pertikaian, yang mengalihkan jurusan nasib para tokoh. Novel hanya menceritakan salah satu segi kehidupan sang tokoh yang benarbenar istimewa, yang mengakibatkan terjadinya perubahan nasib.
"Novel merupakan prosa
rekaan yang panjang yang menyuguhkan tokoh-tokoh dan menampilkan serangkaian peristiwa dan latar secara tersusun" (Purba, 2010: 63). Menurut Stanton (2007: 90) mengatakan bahwa "novel mampu menghadirkan perkembangan satu karakter, situasi sosial yang rumit, hubungan yang melibatkan banyak atau sedikit karakter dan berbagai peristiwa rumit yang terjadi beberapa waktu silam secara lebih mendetail". Di tambahkan pula oleh Jassin (dalam Nurgiyantoro, 2007: 16) mengatakan bahwa "novel sebagai suatu cerita yang bermain dalam dunia manusia dan benda yang di sekitar kita, tidak mendalam, lebih banyak melukiskan satu saat dari kehidupan seseorang dan lebih mengenai sesuatu episode". "Novel biasanya memungkinkan adanya penyajian secara meluas (expands) tentang tempat atau ruang, sehingga tidak mengherankan jika keberadaan manusia dalam masyarakat selalu menjadi topik utama" (Sayuti, 2000: 6-7). Keberadaan manusia dalam masyarakat akan menjadi ide pengarang dalam membuat cerita dalam sebuah novel. Daya imajinasi pengarang sangat tergantung pada suasana yang dibangun dalam cerita novel tersebut. Novel yang disebut juga cerita rekaan akan membawa pembacanya merasakan suasana dan alur dalam ceritanya.

3. Roman

\begin{tabular}{llr}
\multicolumn{1}{c}{ Menurut Frye } & (dalam \\
Nurgiyantoro, 2009 :15) \\
menyatakan"roman dapat diartikan \\
sebagai cerita prosa yang \\
melukiskanpengalaman lahir dari \\
beberapa orang yang berhubungan \\
satu samalain dalam suatu keadaan".
\end{tabular}


Istilah roman berasal dari genre romance dari abad pertengahan, yang merupakan cerita panjang tentang kepahlawanan dan percintaan. Istilah roman berkembang di Jerman, Belanda, Perancis, dan bagian-bagian Eropa daratan yang lain. Ada sedikit perbedaan antara roman dan novel, yakni bahwa bentuk novel lebih pendek dibanding dengan roman, tetapi ukuran luasnya unsur cerita hampir sama. Namun, dalam perkembangannya novel dan roman sudah tidak bisa dibedakan lagi. Novel dan cerita pendek masih dapat dibedakan. "Perbedaan tersebut tidak hanya terletak pada panjang pendeknya cerita, melainkan meliputi aspek aspek pembentuk lainnya, karena pada dasarnya novel merupakan bentuk pencitraan yang bebas, lebih rinci, dan lebih banyak melibatkan berbagai permasalahan yang lebih kompleks" (Nurgiyantoro, 2009: 8-12). Berdasarkan teori di atas dapat disimpulkan bahwa antara novel dan roman untuk sekarang sudah tidak dapat dibedakan. Dapat dilihat perbedaanya apabila melihat unsurunsur pembentuk novel dan panjang pendeknya cerita dalam novel atau roman tersebut.

\section{Cerpen}

Menurut Nurgiyantoro (2007: 10) "cerpen adalah sebuah ceritayang selesai dibaca dalam sekali duduk, kira-kira berkisar antarasetengah sampai dua jam, suatu hal yang kiranya tak mungkindilakukan untuk sebuah nove"Kosasih dkk. (2008: 431) menyatakan "cerpen adalah karanganpendek yang berbentuk prosa". Cerpen atau cerita pendek merupakansuatu karangan prosa yang berisi cerita sebuah peristiwa kehidupanmanusia pelaku atau tokoh dalam cerita tersebut. Dalam karangantersebut terdapat pula peristiwa lain tetapi peristiwa tersebut tidakdikembangkan, sehingga kehadirannya hanya sekadar sebagaipendukung peristiwa pokok agar cerita tampak wajar. Ini berarti ceritahanya dikonsentrasikan pada suatu peristiwa yang menjadi pokokceritanya.Berdasarkan teori di atas dapat disimpulkan bahwa cerpenadalah cerita pendek yang hanya memuat cerita dengan tokoh danpelaku yang dikembangkan sekedarnya saja dan cerita hanyadikonsentrasikan pada satu peristiwa.

5. Drama

Menurut Budianta dkk. (2002 :95) “drama adalah sebuh genresastra yang penampilan fiksinya memperlihatkan secara verbal dialogue atau cakapan diantara tokoh-tokoh yang ada". Dalam pertunjukan drama, yang terpenting adalah dialog atau percakapan para tokohnya diatas panggung karena dialog tersebut menentukan isi dari cerita drama yang dipertunjukkan. Drama sebagai karya sastra sebenarnya hanya bersifat sementara, sebab naskah drama ditulis sebagai dasar untuk dipentaskan. Dengan demikian, tujuan drama bukanlah untuk dibaca seperti orang membaca novel atau puisi.

Drama yang sebenarnya adalah kalau naskah sastra tadi telahdipentaskan. Tetapi bagaimanapun, naskah tertulis untuk membuat drama adalah bagian dari karya sastra. Menurut E. Kosasih (2008: 242) "drama adalah bentuk karya sastra yang tersusun dari unsur intrinsik dan unsur ekstrinsik". Unsur intrinsik adalah unsur yang 
membangun sebuah drama dan berada dalam drama itu sendiri, seperti tokoh, dialog, alur, latar, dan sebagainya. Unsur ekstrinsik adalah unsur yang berada di luar drama, namun berkaitan dengan drama itu sendiri. Unsur ekstrinsik antaralain, sosial, budaya, agama dan lain-lain. Berdasarkan teori-teori di atas dapat disimpulkan bahwa drama adalah sebuah karya sastra yang mengandung unsur intrinsik dan ekstrinsik berupa dialog yang dapat dipentaskan diatas panggung.

\section{Hakikat Perpustakaan}

Perpustakaan pada hakikatnya adalah sistem pengelolaan informasi oleh sumber daya manusia yang terdidik dalam bidang perpustakaan, dokumentasi, dan informasi. Fungsi perpustakaan sebagai media pendidikan, tempat belajar, penelitian sederhana, pemanfaatan teknologi dan informasi, kelas alternatif, dan sumber informasi. Sedangkan tujuan perpustakaan adalah sebagai bagian integral yang mendukung proses belajar mengajar. Keberadaan perpustakaan yang representatif dalam jangka panjang dimaksudkan untuk: (1) menumbuh kembangkan minat baca dan tulis, (2) mengenalkan teknologi informasi, (3) membiasakan akses informasi secara mandiri, (4) memupuk bakat dan minat.

\section{METODE PENELITIAN}

Pemilihan mitra dilakukan dengan sistem purposive sample (sampel bertujuan). Berdasarkan pengamatan dan wawancara informal terhadap para relawan di Balaraja maka dapat disimpulkan bahwa pelatihan menulis karya ilmiah dan sastra sangat diperlu untuk dilakukan, hal ini ditunjang dengan berbagai alasan sebagai berikut. Pertama, keterampilan terhadap menulis karya ilmiah dan sastra ini sangat diperlukan karena sumber buku yang dijadikan acuan sebagai pemberdayaan masyarakat melalui taman bacaan. Kedua, keterampilan menulis merupakan salah satu keterampilan produktif, sehingga para relawan diharapkan untuk aktif dalam kegiatan ini. Ketiga, pemberdayaan masyarakat diharapkan untuk meningkatkan kualitas hidup dari masyarakat dengan memperbanyak membaca dan menulis. Keempat, pelatihan ini diharapkan dapat membantu pemerintah dalam hal mewujudkan tujuan pendidikan nasional.

Metode atau teknik yang akan kami lakukan dalam pengabdian masyarakat ini adalah teknik activelearning, inkuiri, metode objek langsung, tanya jawab, deskriptif hingga pada praktek yang berkaitan dengan menulis karya ilmiah dan sastra. Penggunaan teknik dan metode yang telah dijelaskan diharapkan bahwa para relawan mampu lebih produktif lagi. Sehingga diharapkan media yang digunakan dalam pemberdayaan masyarakat Balaraja dapat dilakukan sendiri.

\section{HASIL DAN PEMBAHASAN}

Ada beberapa temuan yang didapatkan oleh tim pelaksana pada kegiatan pengabdian masyarakat ini, antara lain sebagai berikut:

1. Peserta pelatihan sangat antuasias dalam mengikuti setiap tahapan pelatihan dalam menulis karya ilmiah dan sastra.

2. Antuasias dari peserta ditunjukkan melalui pertanyaan yang diajukan oleh hampir seluruh peserta. Pertanyaan yang diajukan oleh peserta sebagai berikut:

a. Bagaimanakah cara menyusun kajian teori dan cara pengutipan? 
b. Bagaimana cara menimbulkan minat dalam menulis karya sastra?

c. Apakah perbedaan antara daftar pustaka dan catatan kaki?

d. Bagaimana perbedaan karya ilmiah dan karya sastra?

e. Bagaimana awal memulai suatu penelitian?

f. Apa indikator yang menyatakan bahwa suatu karya ilmiah dinyatakan plagiat?

g. Bagaimana proses penerbitan suatu karya sastra?

3. Para peserta umumnya adalah mahasiswa tingkat akhir, sehingga materi tentang karya ilmiah sangat diminati.

4. Para peserta masih banyak yang belum memahami tahapan-tahapan dalam penulisan karya ilmiah.

5. Para peserta melakukan penulisan karya imiah dan sastra berdasarkan jurusan masing-masing, dalam hal ini masih banyak ditemui kesalahan baik secara isi maupun teknik.

6. Hasil kegiatan ini dapat dilihat pada lampiran.

\section{Hasil}

Peserta kegiatan ini adalah masyarakat Balaraja yang bergabung dalam Relawan "Pustaka Muda Mandiri", Relawan "Forum Pelajar dan Mahasiswa Kabupaten Tangerang" dan kelompok pemuda Balaraja. Mereka memiliki latar belakang yang beragam, ada yang berprofesi menjadi guru, karyawan serta mahasiswa dari berbagai jurusan dan universitas misalnya jurusan kedokteran, hubungan internasional, ekonomi, bimbingan konseling, sejarah, hukum dan sebagainya. Perbedaan latar belakang inilah yang menjadikan pemateri menyampaiakan materi karya ilmiah dan sastra secara umum dan sesuai dengan penelitian. Berbagai hasil yang diperoleh dari kegiatan ini sebagai berikut.

\section{Kelompok Karya Ilmiah}

1. Penentuan Masalah-masalah Penelitian sesuai dengan Jurusan atau Profesi Peserta.

Masalah-masalah yang dikemukakan oleh peserta sangat beragam karena peserta memilki latar belakang yang berbeda. Contoh masalah yang dikemukakan sebagai berikut. Pertama, masaslah yang dikemukakan oleh seorang guru Sejarah yaitu minat siswa dalam memahami serta minat yang kurang terhadap mata pelajaran sejarah. Kedua, masalah yang dikemukakan oleh mahasiswa kedokteran yaitu perkembangan obat dari masa dulu sampai sekarang dilihat dari dampak pemakaiannya serta sejarah pembuatannya. Ketiga, masalah yang dikemukakan oleh mahasiswa ekonomi yaitu bagaimana daya minat pembeli yang menurun sangat memengaruhi pasar. Keempat, masalah yang dikemukakan oleh karyawan yaitu tuturan atau kualitas percakapan yang rendah akan memengaruhi keberhasilan suatu informasi dikemukakan. Kelima, masalah yang dikemukakan mahasiswa bimbingan konseling tentang pengaruh lingkungan terhadap kejiwaan seseorang sangat berpengaruh terutama sikap masa kini yang banyak terjadi yaitu "bully". Keenam, tentang plagiat yang terjadi yang dapat menimbulkan masalah seperti kasus pengunduran seorang guru besar karna suatu kasus plagiat terhadap karya orang lain.

2. Penentuan Judul dari Masalah yang Diperoleh. 
Judul-judul yang diperoleh dari masalah yang dikemukakan di atas adalah:

a. Pengaruh Motivasi terhadap Pembelajaran Sejarah di SMPN 1 Balaraja.

b. Perkembangan Sejarah dari Tahun 1945 sampai Sekarang Ditinjau dari Etnografi Budaya.

c. Pengaruh Lingkungan Terhadap Dampak Perkembangan Psikologis Remaja.

d. Hubungan Minat Konsumen terhadap Keberlangsungan Perusahaan.

e. Pengaruh Kualitas Produk terhadap Peningkatan Daya Tarik Konsumen.

f. Minimasi Pemborosan pada Proses Produksi Kertas PPC 80 GSM dengan Pendekatan Lean Six Sigma di PT Indah Kiat PULP and Paper Tbk Tangerang Mill

g. Pengaruh Plagiat terhadap Hasil Karya yang Dihasilkan.

h. Perbedaan Kualitas Obat Herbal dan Obat Kimia.

i. Perkembangan Dunia Kedokteran Dilihat dari Sejarah Perkembangan Obat.

\section{SIMPULAN}

Kegiatan pengabdian masyarakat ini memberikan nilai positif, karena dapat memberikan materi yang bermanfaat kepada para relawan Balaraja yang mayoritas dari mereka merupakan mahasiswa dari beberapa perguruan tinggi, sehingga mereka diharapkan dapat memahami tentang bagaimana menulis sebuah karya ilmiah dan menulis sastra dengan baik. Dengan demikian para relawan tidak mendapatkan kesulitan dalam membuat sebuah karya ilmiah maupun karya sastra.
Saran dalam pelaksanaan kegiatan abdimas ini adalah agar kegiatan ini dapat terus dilanjutkan dengan mitra pustaka lainnya. Selain itu, pera aktif para relawan sangat diharapkan agar masyarakat Indonesia terhindar dari buta aksara sesuai dengan norma-norma yang berlaku dalam masyarakat Indonesia

\section{DAFTAR PUSTAKA}

Aswinarko dan Ahmad, M.G.. (2014). Pengantar Sosiologi Sastra. Jakarta: Unindra Press

Akhadiah dan Nandar. (2011). Pembinaan Kemapuan Menulis Bahasa Indonesia. Jakarta: Erlangga.

Budianta, M. (2002). Membaca Sastra. Jakarta: Indonesia Tera.

Esten, M. (2000). Kesusastraan Pengantar Teori dan Sejarah. Bandung: Angkasa Raya.

Hanum, K. (2004). Sastra Indonesia dalam Enam Pertanyaan. Jakarta: Pustaka Utama Gratifi.

Kosasih, E. (2008). Apresiasi Sastra Indonesia. Jakarta: Nobel Endumedia.

Pradopo, R. (2008). Beberapa Teori Sastra Metode Kritik dan Penerapannya. Yogyakarta: Pustaka Pelajar.

Ratna, N.K. (2007). Estetika Sastra dan Budaya. Yogyakarta: Pustaka Pelajar.

Sayuti, S.A. (2000). Berkenalan dengan Prosa Fiksi. Yogyakarta: Gama Media.

Suparno dan Yunus, M. (2005). Keterampilan Menulis. Jakarta: UT.

Stanton, R. (2006). Teori Fiksi. Yogyakarta: Pustaka Pelajar. 
Wiyatmi. (2006). Pengantar Kajian Sastra. Yogyakarta: Pustaka Pelajar..

Zulfa. (2007). Metode Penelitian Susastraan. Tangerang: Pustaka Mandiri.
Zulfahanur. (2007). Teori Sastra. Jakarta: Universitas Terbuka. 